\title{
From Electronic to Smart Library Systems: Concept, Classification of Services, Scheme of Work and Model
}

\author{
Ruslan A. Baryshev* \\ Siberian Federal University \\ Krasnoyarsk, Russian Federation
}

Received 21.01.2019, received in revised form 28.02.2021, accepted 06.03.2021

\begin{abstract}
The university library is presented as a complex system that includes elements with various properties and challenges. Any structural change inevitably affects the activity of all its components. This paper discusses the concept of an anticipated smart library, the services that can be transferred to it, and its scheme of work and model.

This paper presents a certain set of technical solutions deliverable through the smart library of a university.

Over 200 publications, mainly by foreign scholars, have been analysed because of the lack of research in Russia on smart library services. The smart library system is designed to provide information services in any form and on any digital device through classical and service networks based on smart services. Smart library services are classified by two main characteristics: the library activity types (e. g. general services, scientific and educational) and the ways of obtaining information (e. g., traditional, online and smart). This paper presents the scheme of a smart library, based on which the model of a university smart library is constructed.

The research results may be best limited to university libraries.

The results have practical applications in the Library and Publishing Complex of Siberian Federal University. Consequently, a new library information environment has been developed and integrated into the university's information space.
\end{abstract}

Keywords: university library, smart library, electronic library, library services, information technology in libraries, model, classification of services, smart services, online services, information resources.

Research area: pedagogy.

Citation: Baryshev, R.A. (2021). From electronic to smart library systems: concept, classification of services, scheme of work and model. J. Sib. Fed. Univ. Humanit. Soc. Sci., 14(3), 426-443. DOI: $10.17516 / 1997-1370-0732$.

(C) Siberian Federal University. All rights reserved

* Corresponding author E-mail address: r_baryshev@bk.ru 


\title{
От электронных до смарт-библиотечных систем: концепция, классификация сервисов, схема работы и модель
}

\author{
P.A. Барышев \\ Сибирский федеральный университет \\ Российская Федераиия, Красноярск
}

\begin{abstract}
Аннотация. Университетская библиотека представлена как сложная система, включающая в себя элементы с различными свойствами и изменениями. Любое структурное изменение в системе неизбежно влияет на деятельность всех его компонентов. В настоящей статье рассмотрены концепция смарт-библиотеки, встроенные в нее сервисы, а также схема ее работы и модель.

В статье представлен определенный набор технических решений, предоставляемых пользователю через смарт-библиотеку университета.

Более 200 публикаций, в основном зарубежных ученых, были проанализированы по «умным» библиотечным сервисам. Смарт-библиотечная система предназначена для предоставления информационных сервисов в любой форме и на любом цифровом устройстве через классические и новые сервисы, работающие по технологии опережения запроса пользователя. Смарт-библиотечные сервисы классифицируются по двум основным характеристикам: тип библиотечной деятельности (например, общие, научные и образовательные сервисы) и способ получения информации (например, традиционные, онлайновые и смарт-сервисы). В статье представлена схема работы смарт-библиотеки, на основе которой построена модель университетской смарт-библиотеки. Результаты исследований могут быть применены в работе других университетских библиотек.

Результаты исследования имеют практическую апробацию в Библиотечноиздательском комплексе Сибирского федерального университета. В результате исследования новая библиотечная информационная среда была создана и интегрирована в информационное пространство университета.
\end{abstract}

Ключевые слова: университетская библиотека, смарт-библиотека, электронная библиотека, библиотечные услуги, информационные технологии в библиотеках, модель, классификациясервисов, смарт-сервисы, онлайн-сервисы, информационные ресурсы.

Научная специальность: 13.00.00 - педагогические науки.

\section{Introduction}

Today the electronic library is considered an independent, prospective library form in the information community (Nokhrin, 2005). It is a social and technical complex oriented towards performing traditional and nonconventional library functions on an essentially new technological basis. This basis includes new information technologies, peripheral hardware, soft- ware, mathematical and linguistic support, a means of telecommunication and network information resources.

The electronic library becomes the most important instrument of knowledge management, while, at the same time, it does not go beyond its traditional functions connected with knowledge accumulation and storage. Tryamkina (2017) wrote that within knowledge management, the electronic library turns knowl- 
edge into a key resource of library information activities development and efficiency.

Zamyatin (2011) observed that an important advantage of electronic libraries is their mobility; dynamism of exchange and communication with the global information environment and ability to work with not only static text but also fast-changing, constantly updated, interactive resources (e. g., hypertext documents, websites).

The main goal of the university electronic library is successful learning, doing research and involving students in the university's social, sports and cultural activities. Thus, electronic library systems will reach new levels of development, if they have the ability to analyse user behavior information (Tsibulsky et al., 2017).

A library's flexibility in adapting rapidly to changing needs and new technologies is of utmost importance. To achieve success, electronic libraries must offer high-quality services that satisfy readers' requirements and exhibit great flexibility in their activities (Pinto et al., 2012).

Traditional library services are being modified and enhanced in the online environment. Burgess (2010) asserted that modern libraries promote the availability of their useful mobile information resources and services and access to information in the field from mobile devices to support research. They deliver services to users via the Internet, smartphones and other handheld devices.

Little (2013) argued that university electronic libraries store and issue information and render some services upon users' request only. Noskov et al. (2016) wrote that they are warehouses of data and resources for performing information services upon students', university faculty's and administrative staff's request. Kuleva (2014) argued that the electronic library that only reacts to users' enquiries is passive.

Kaklauskas et al. (2007) described the transformation from the electronic library to the smart library, which provides advanced services, such as personalisation, hypertext, computer-aided design, knowledge-mining and cross-media services. All these services transformed the electronic library into the smart library, which is a more active, professional and intelligent storehouse of practical knowledge offering intelligent opportunities for users (Aghakhani et al., 2013; Jeng, 2014).

Besides, Mohapatra (2017) observed that digital information storage and information communication technologies together can revolutionise and modernise library systems, transforming them to smart libraries. In the big data environment, the smart library, with the development of information technology and changes in user needs, continues to transform and reform, resulting in a new form (Zhao et al., 2019).

Cao et al. (2018) stated that traditional libraries can transform to smart libraries by strategic design and implementation of advanced technologies, such as cloud computing, data mining and artificial intelligence but that they also need to consider service building, user cultivation and librarian training.

The smart library concept has been discussed extensively in previous research, mainly by Western scholars, including Cao et al. (2018), Johnson (2013), Sreekumar (2012), Zimmerman et al. (2018), Simović (2018), Leorke et al. (2018), Bajic et al. (2008), Burgess (2010), Dean et al. (2010) and Pan (2010). The Russian pool of works is represented by a limited number of researchers, such as Ivshina (2017), Vasilieva (2016) and the works of researchers from the Siberian Federal University including Noskov et al. (2017) and Baryshev et al. (2014, 2018). These authors contend that a smart library should be user-centric, that is, capable of automatically capturing and understanding the user needs and providing corresponding resources and services. Smart library systems enable libraries to become more interactive, adequate and user-friendly.

The smart library collects information about its users, analyses their biographical data, inquiries and search history. The information about the user available at the library is the context in this case. This information has dynamics determined by the changing status of the user (e. g., transition from one year of study to another, admission to a postgraduate or $\mathrm{PhD}$ programme etc.), personal interests and information demands connected with learning 
and research activities and hobbies that also change over time (Zadorozhnyuk et al. 2018). The dynamic context determines content changes in the library information offered to the user. Tracking the dynamics of the user's information demands, the smart library searches for and provides the information relevant to meet these demands without waiting for the user's enquiry (Baryshev et al., 2015; Baryshev, 2016). It has a positive impact on the development of the user's information demands.

Besides, the smart library can offer a wide range of additional services, including the list of specific authors' publications, citation data, reviews available for the requested work, the list of other works on the topic etc. This integrated approach with the reader is beyond traditional library work and characterises its more active position.

Zhang at al. (2018) argue that the core of the smart library is the integration of books and related data, as well as digital and space resources, based on the realisation of the comprehensive informatisation of the library. Using a large data intelligent analysis platform, library management services are intelligent and personalised, and the readers' needs are prioritised to improve their experience.

A review of domestic and foreign sources has shown that researchers' interest is directed to aspects of the smart library activity of higher education institutions that are connected with the support of the educational and scientific activity of students and employees. The development and expansion of library educational functions, as well as support for users' scientific activity, including students' independent work, are widely discussed. A new theory and methodology are required to update the conceptual basis of library activity; in this case, it is necessary to create a new model library of a university called smart library.

\section{Literature review}

\section{The concept of Smart Library}

We will analyse the concept of SMART from the perspective of a modern university library. The mnemonic abbreviation SMART is formed by the first letters of the following English words: S - Specific, M-\$5easurable,
A - Attainable, Achievable, R - Relevant, T Time-bound (Ivshina, 2018).

Zimmerman et al. (2018) observe that the term 'smart library' was coined by Aittola, Ryhanen and Ojala in 2003, and librarians have been striving to implement smart libraries in different ways ever since. The term first appeared in the academic corpus in 2003.

The term 'smart library' appears in various contexts as a synonym for the concept of an 'intellectual library', 'digital library' or 'virtual library' (Baryshev et al., 2018). The term 'smart' means flexible, adaptive, extendible, acknowledging and human. The smart library is a hardware and software complex with a wide range of opportunities for searching and providing necessary information to virtual users according to their inquiries and requirements. Another definition of the smart library is of a library that provides services that are interactive, innovative, informative, real, changing and international (Baryshev et al., 2015).

Shen $(2018,2019)$ stated that there are three future scenarios of smart libraries, including the digital octopus, smart village and virtual assistant concepts, which are detailed in the following narrative. In the first concept, the library acts like an 'octopus with a central head and multiple tentacles' reaching out; pulling all the data, expertise and knowledge back in; and bringing them together. Here, the library is conceptualised as a distributed system embedded within the cyber-physical-integrated environment to collect data and combine information, push these back and forth and communicate them across the user. In the smart village view, the library will be the 'heart' of all data, bridging gaps between users situated on the different spectrum and dimensionality of data workflows. It will function as a central hub for data gathering, processing, sharing and communication. In the third scenario, in an age of both information overload and siloed systems, aggregating and accurately reporting on research output are challenging objectives. Struggling to function under conditions of electronically mediated data and information overload, researchers look to the smart library and information solutions. Such solutions can 
spontaneously self-assemble constituent pieces of data into a knowledge package with a particular property and then bring it to the individual with the relevant interest.

Schöpfel (2018) stated that the smart library concept can be understood as an approach that introduces consistency into several recent 'modern' library developments in the urban environment.

Mohapatra et al. (2017) observed that due to the use of smart technologies in modern library systems, they are able to provide smart services to users, thus becoming smart libraries.

Li et al. (2016) argued that smart library refers to the smartness of the library building the integration of library building equipment, computer networks, communications technology and sensor monitoring.

Dong Yan (2010), a Chinese scholar, believes that smart library $=$ library + IoT + cloud computing + intelligent equipment, realising intelligent services and management through Io T. Shiwei Wang (2012) believes that the smart library is based on digital; network and intelligent information technologies focusing on collaborative management; ubiquitous benefit service and green, sustainable development of the future library.

Schöpfel (2017) notes that the smart library is a mixture of information technologies, mobility, digital nomads and local community. Its concept may be helpful to consider academic libraries from 'outside' as a challenge for innovative concepts based on local resources and history, while at the same time, experimenting with new digital services, instigating (not only suffering!) new uses of information and knowledge, and combining data management and grid architecture with modern lifestyle.

Wang (2011) noted that a smart library realises the associations between books, between books and people and between people anywhere and at any time. Digitisation, networking and intelligence are the informational and technical basis of the smart library. The smart library is people-oriented, with sustainable development and user convenience at its heart, and aims to satisfy the increasing information requirements of readers.
$\mathrm{Wu}$ (2012) supposed that a smart library is a more advanced development of the hybrid and digital libraries. Within the environment of the IoT, the smart library relies on cloud computing technology and intelligent equipment; understands the book-book, book-people and people-people associations; and provides intelligent services for users.

Yan (2010) asserted that the smart library is a model of a smarter way to change the interactivity of users and library systems by using a new generation of information technology to improve the clarity, flexibility and responsiveness of the interaction, smart services and management. As for the services, they must meet user needs, and be user friendly and automatic

Luterek (2018) viewed smart library systems as enabling library users to retrieve information based on what they mean rather than on what they say.

Wang (2017) wrote that the smart library is a higher development form of library, after the digital library and the compound library, which rely on sensors, cloud computing and other technologies to achieve interoperability between books and readers to provide a full range of smart services. Besides, he wrote that the smart library is a kind of intelligent construction applying intelligent technology to the library construction. It is the organic combination and innovation of intelligent buildings, highly automated management and the digital library.

\section{Review successful cases regarding the smart library}

The smart library, described by Hubert et al. (2018), is divided into four sections, namely, intelligent and organised, apomediated and personalised.

- Intelligent. The library is intelligent: self-renewing, flexible, functional, integrated, efficient, resilient, autonomous and sensitive (adaptive).

- Organised. The library is organised: turning the unorganised web of information into a systematic and useable body of knowledge by exhaustively describing and linking every piece of data to enable ease of access. 
- Apomediated. The library is apomediated: the library stands by the users and guides them to high-quality information and services.

- Personalised. The library is personalised analogously to what various service providers such as search engines and the media offered their clients on various Internet platforms.

Aithal (2016) wrote that in the smart library, all library functions are automated and a central library will digitise all the information and provide services to all public and educational and research institutional libraries in e-form. These local libraries should have electronic reading systems to retrieve any information based on search facility to the readers. Such local client libraries will become paperless systems. This concept transforms local libraries into e-resource centres. A user can get access to any information through e-books, enewspapers, e-magazines, e-journals and their back volumes through the search facility. Such smart libraries have advantages in terms of reduced cost to maintain resource-full libraries without any physical copies of the resources. A developing country should have such smart libraries to cater to the information needs of its citizens. Depending on the smart library model, either the national government can spend on the national central smart library or through subscription fees to all local client libraries or users, the system can generate its revenue for maintenance.

In the smart library system, the client libraries act as electronic information resource centres networked with the national smart library through internet or private networks. Such client libraries functioning in educational institutions by replacing conventional libraries can be termed information resource centres (IRC). IRCs will provide huge benefits to educational institutions as well as users (faculty members and students) because of unrestricted information availability and reduced cost. This new model will also remove the constraints of unequal sharing of library resources between rural and urban institutions.

Cao et al. (2018) distinguishes between similar types of smart library and divides the concepts associated with the smart library building into three dimensions: technology, service and human. Aligning to the three main dimensions of smart libraries, the study clarifies the concept of the smart library and offers strategic principles: integration of infrastructures, construction of service and human learning. To summarise, the fundamental factors and key conceptual components of the smart library can be classified into three categories: smart technology (IoT, data mining and AI), smart service (user-centred service) and smart people (user and librarian).

Schöpfel (2018) has pointed out that the smart library can be described in four dimensions: smart services, smart people, smart place and smart governance.

Wang (2011) wrote in 2004 that several libraries, museums, universities and public libraries in Ottawa, Canada established a 'smart library' coalition using a single search engine to provide a one-stop reader service.

Hui (2018) pointed out that the smart library model is used to build a mobile reading promotion platform. The platform combines library and university library resources, and uses the smart library model and a full coverage WiFi communication network to realise the construction of a mobile reading promotion platform. There are five main elements of library reading promotion, namely, reading resources, reading promotion subjects, reading promotion media, reading promotion activities and readers.

Zhang et al. (2019) wrote about the Smart Discovery Platform - Watson. Watson is a robot developed by IBM that 'reads' about 200 million pages of content and can retrieve hundreds of millions of pages of material and give answers within 3 seconds, effectively helping readers quickly using a little data.

Pandey (2018) proposes a smart solution for libraries in Oman by designing an application called the Smart Library Management System by using the concepts of Radio Frequency Identification (RFID) and Mobile Io T. The new system will manage and control all the information in the library as well as providing several benefits for the staff and students. This application includes several forms that will be used by the library staff and students. As a case 
the requirements have been gathered at Middle East College, Muscat and Oman Library and then the study is done.

However, the above-mentioned research papers do not examine the aspect of modernisation of the university library as a smart system of the information and educational environment; besides, the library possibility is not considered to build an individual trajectory for a reader in his/her educational or scientific activities using modern services.

\section{Research Methodology \\ Research objective and task}

The research objective of this paper is to develop the system of theoretical and methodological provisions of the smart library integrated into the information and education environment of the university.

According to the research objective, the following tasks are set and carried out:

1. Develop the conceptual bases and the model of the university smart library.

2. Offer the classification of the university smart library services by various criteria.

3. Carry out experimental verification of overall performance of the university smart library.

\section{Research stages}

The work carried out within the described research can be divided into three main stages.

In the first stage (2007-2009), a detailed analysis of scientific sources was carried out. The results revealed the existing approaches to the development of smart libraries in higher education institutions; the smart library concept was formulated.

In the second stage (2010-2013), the needs of the user were studied, theoretical and practical requirements and recommendations for the smart library model's creation were developed, and the technology and technique for practical applications of the smart library in the educational process were defined.

In the third stage (2013-2017), the process of introduction and approbation of results was investigated, and experiments were carried out to check the efficiency of the smart library's introduction in the educational process.

\section{Experimental base}

The experimental base of this research comprised the Scientific Library of the Siberian Federal University (rendered hereafter as SibFU).

\section{Classification of smart library services}

The model of a smart library includes, according to the authors, services which can be classified by two criteria: the types of activities (e. g., general services, scientific and educational services) and the ways of obtaining information (e. g., traditional services, online services and smart services). The challenge of the services classification is that using information and communication tools, they can be referred to all presented categories at the same time. For example, search for information, electronic document delivery, renewing books borrowed from the library, etc.

General services are focused on rendering traditional information and library services and include the following services: access to information search, interlibrary subscriptions, electronic document delivery, 'Book on demand' or 'Press on demand', Ordering and booking editions, consultations (reference), virtual help service, antiplagiarism services, the list of titles borrowed from the library, history of book issue and the prolongation of book use.

Scientific services are aimed at the support of users' publication activity and include a number of services from literature selection for writing a scientific paper to its publication in high-ranking journals.

A specific role is played by Educational services, which allow for analysing university teaching and methodological literature supplies on various disciplines in paper and electronic forms, as well as developing the maintenance of the teaching process at the university.

Thus, the presented groups of services in total meet the majority of information, scientific and educational demands of students and faculty staff. Developing and launching new library services provides efficient access to bibliographic and full text domestic and international resources of the scientific library of SibFU with compliance with the copyright and intellectual property protection laws. Besides, the automated system 
redistributes workload between the library staff, affording working hours for developing their professional competences.

For the systematisation of the library services and their representation in the model of the smart library, the authors of this paper have developed a classification based on two criteria: library activities (Table 1) and the ways of obtaining information by the users (Table 2). Through library activities it is possible to determine general, scientific and educational services.

This list defines library activities, outlining the purposes and tasks of the university in organising the information and education environment. It has been mentioned above that a specific characteristic of the smart library is the ability to ensure an anticipated enquiry for providing information based on the analysis of the user's information. This characteristic transforms a number of the existing services dramatically and allows to offer new ones. The library has already mastered a number of traditional services transferred to the online mode. The next step in developing the electronic library is the smart service.

We define the ways of obtaining information as follows: traditional services; traditional services working online and smart services. A more detailed description of the technology of smart services is can be found in Tsibulsky et al.'s work (2017).

Thus, most of the services transfer from traditional one to online services, and by means

Table 1 . The list of the smart library services by the library activities

\begin{tabular}{|c|c|c|c|c|}
\hline № & Name of services & $\begin{array}{l}\text { General } \\
\text { services }\end{array}$ & $\begin{array}{c}\text { Educational } \\
\text { services }\end{array}$ & $\begin{array}{l}\text { Scientific } \\
\text { services }\end{array}$ \\
\hline 1. & Access to information search & + & & \\
\hline 2. & Interlibrary subscription & + & & \\
\hline 3. & Electronic document delivery & + & & \\
\hline 4. & 'Book on demand' or 'Press on demand' & + & & \\
\hline 5. & Ordering and booking editions & + & & \\
\hline 6. & Consultations (reference) & + & & \\
\hline 7. & Virtual help service & + & + & \\
\hline 8. & Anti-plagiarism & & + & + \\
\hline 9. & Viewing the list of books borrowed from the library & + & & \\
\hline 10. & History of books issue & + & & \\
\hline 11. & Prolongation of books use period & + & & \\
\hline 12. & Literature on disciplines required & & + & \\
\hline 13. & Books supplies & & + & \\
\hline 14. & $\begin{array}{l}\text { Selection of literature for the publication in scientific } \\
\text { journals }\end{array}$ & & & + \\
\hline 15. & Scientific paper data visualisation & & & + \\
\hline 16. & Choosing a scientific journal & & & + \\
\hline 17. & Verification of a journal & & & + \\
\hline 18. & Forming a list of references & & & + \\
\hline 19. & $\begin{array}{l}\text { Entering of the publication into the Russian Science Ci- } \\
\text { tation Index database }\end{array}$ & & & + \\
\hline 20. & Search for collaborations & & & + \\
\hline 21. & Verification of scientometric indicators & & & + \\
\hline 22. & Register for the consultation & & & + \\
\hline
\end{tabular}


Ruslan A. Baryshev. From Electronic to Smart Library Systems: Concept, Classification of Services, Scheme of Work...

Table 2. The list of services of the smart library by the ways of obtaining information

\begin{tabular}{|c|c|c|c|c|}
\hline № & Name of the services & $\begin{array}{c}\text { Traditional } \\
\text { services }\end{array}$ & $\begin{array}{c}\text { Traditional } \\
\text { services online }\end{array}$ & $\begin{array}{c}\text { Smart } \\
\text { services }\end{array}$ \\
\hline 1. & Access to information search & + & + & + \\
\hline 2. & Interlibrary subscription & + & + & \\
\hline 3. & Electronic document delivery & & + & + \\
\hline 4. & 'Book on demand' or 'Press on demand' & & + & \\
\hline 5. & Ordering and booking editions & + & + & \\
\hline 6. & Consultations (reference) & + & & \\
\hline 7. & Virtual help service & & + & + \\
\hline 8. & Anti-plagiarism & & + & \\
\hline 9. & Viewing the list of books borrowed from the library & + & + & \\
\hline 10. & History of books issue & + & + & \\
\hline 11. & Prolongation of books' use period & + & + & + \\
\hline 12. & Literature on disciplines required & & + & + \\
\hline 13. & Supply of Books & + & + & + \\
\hline 14. & $\begin{array}{l}\text { Selection of literature for the publi- } \\
\text { cation in scientific journals }\end{array}$ & + & + & + \\
\hline 15. & Scientific paper data visualisation & & + & + \\
\hline 16. & Choosing a scientific journal & + & + & + \\
\hline 17. & Verification of a journal & + & + & \\
\hline 18. & Forming a list of references & + & + & + \\
\hline 19. & $\begin{array}{l}\text { Entering of the publication into the Rus- } \\
\text { sian Science Citation Index database }\end{array}$ & + & + & + \\
\hline 20. & Search for collaborations & + & + & \\
\hline 21. & Verification of scientometric indicators & + & + & + \\
\hline 22. & Registering for consultation & + & + & + \\
\hline
\end{tabular}

of information and communication technologies they become a smart service. This approach does not preclude all forms of services for the readers from visiting the library and borrowing traditional resources to obtaining information at any convenient time and at any place taking into account users' inquiries and demands. Thus, the library provides an integrated approach to formation and granting international and domestic information resources and develops the services that allow the satisfaction of users' needs efficiently.

The implementation of innovative technologies and their synthesis with traditional services transforms library work; this acts as the crucial aspect of all service systems of the university library today. Introducing innova- tions is aimed at meeting the users' demands. The main objective is to provide users with necessary sources of information at any time, in any place and in any format.

\section{Schematic difference between \\ the working of electronic \\ and smart libraries}

The schematic difference between the working of electronic and smart libraries is presented in Fig. 1.

Figure 1 demonstrates that during the traditional work of the electronic library, the user addresses his/her personal account, which is a single point of access to all online services, makes inquiries, and thereafter services interact with various elements of the library system. 


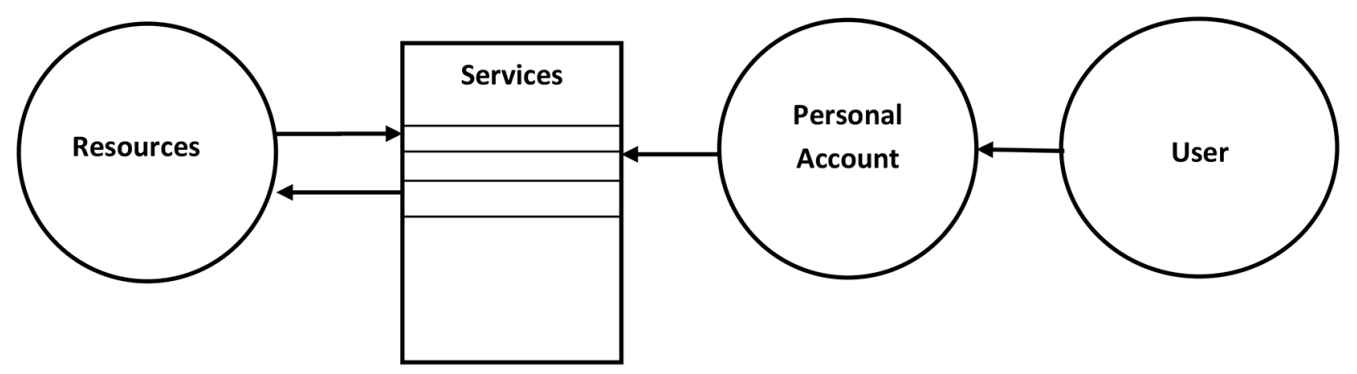

Fig. 1. Scheme of electronic library work

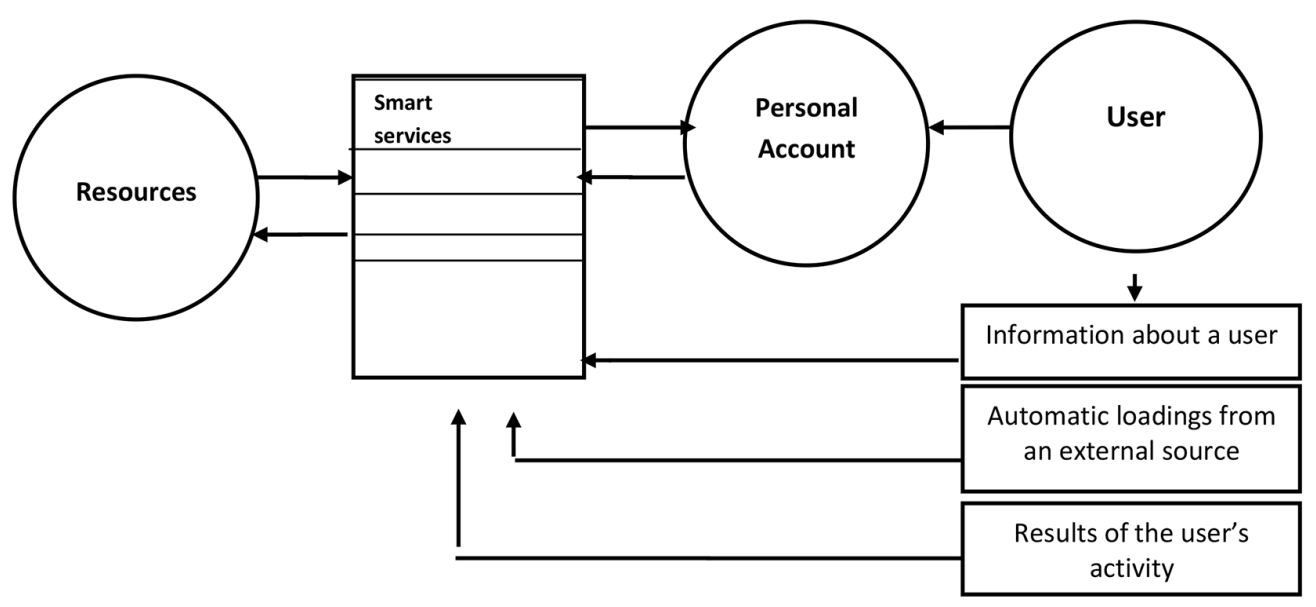

Fig. 2. Scheme of how the smart library works

Finally, all required resources or services are delivered to the user's personal account.

This library works as a passive one because of the fact that the cycle of its activity is started by the user's enquiry, and the delivery of required information is the final point of the cycle (see Fig. 2).

The electronic library becomes smart when the cycle of its activity is started before the user's enquiry for information. In this way, a first-year student can find the recommended literature on the disciplines he studies in the first semester as soon as he authorises his personal account. There is no need to send any enquiry as the library, being a smart element of the information and education environment, collects all the data available about the student and gives recommendations. When interacting with the user, the library is enriched with the information about the user; analyses the history of his requests and creates new, more personalised recommendations reflecting the user's educational, scientific and leisure interests. In this mode of interaction, the library becomes not just a warehouse of resources but a guide on local and global information resources available; it is able to support and direct the user's cognitive activity.

\section{Smart library model}

The general scheme of a smart library model is presented in Fig. 3.

Figure 3 shows that a reader has several opportunities to access resources: traditionally, by means of addressing the enquiry to a librarian; via a computer in the reading room or via any device that allows entering a personal account no matter where the user is located physically. This system of access to resources includes the electronic directory of digital and printed resources, electronic directories of 


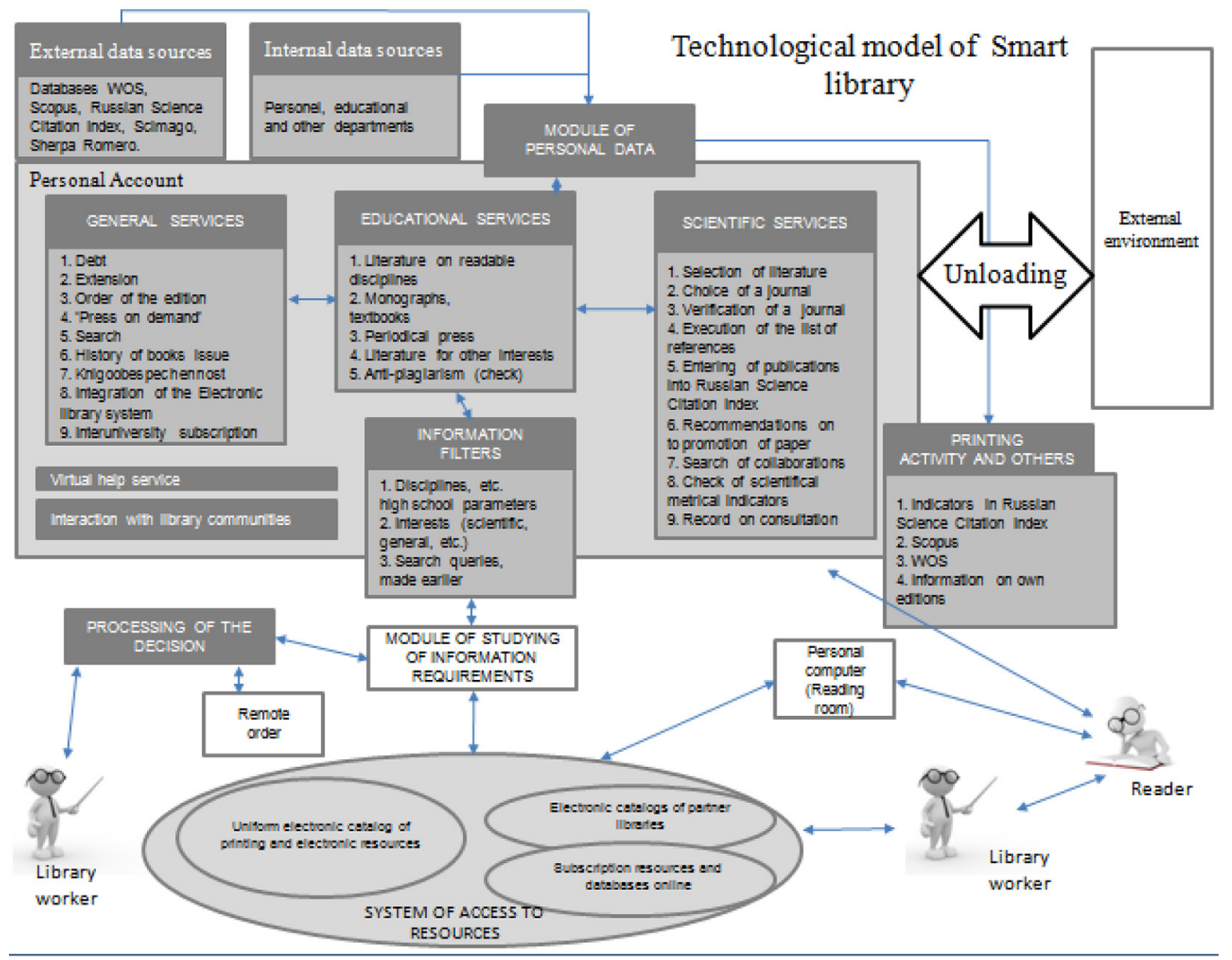

Fig. 3. Smart library model

partner libraries and also subscription to other resources and databases.

When addressing a librarian the reader receives all the services demanded, but as he does not enter his personal account, the automated modules of the smart library do not receive the information about the reader and do not work in a streaming mode. When addressing the smart library via the computer located in the reading room, without authorisation, the user receives all passive services developed by a classical principle 'a request - an answer'. To this type of services the following services such the Verification of the Journal, Antiplagiarism, etc. can be referred.

Logging into the personal account after authorisation starts the core function of the smart library, which first addresses all the connected external data sources that store the information about the user and further addresses all internal information systems integrated into the university electronic information and education environment. In the event of any changes or new data about the user uploaded to the personal account, the library corrects information services for the user. Then all additional modules and smart services are started consequently.

All users' inquiries and data on their activity in the system get to the module of studying information demands, then the model of a reader's personal forms. Besides, being an element of the university's electronic information and education environment, the library possesses the data on the reader from HR, educational and other departments. Also the library information system has an opportunity to obtain data for the reader from external sources such as the WOS, Scopus, Russian Science Citation Index databases, etc. In the library information system, the listed data acts as information filters for information screening. Then the search 
of relevant information in internal and external resources which is provided to the user is carried out.

Information is processed continuously (in a streaming mode): any activity on the part of the user or change of his status activates the search and provision of the updated data.

Thus, the user does not need to look for information, as the library itself selects the relevant sources according to the personal data. Unlike the selective information dissemination service currently in use the smart library processes information that arrives from the user in a streaming mode. The model of personal data is dynamically reconstructed when performing search queries. In this way, the library turns from acting as a passive store of information into an interactive partner. Anticipating the reader's enquiry, the information relevant to the reader's educational and scientific interests, hobbies and preferred leisure activities are selected automatically.

\section{Results and analysis}

The smart library model is based on information resources. SibFU scientific library information resources are formed according to the main academic programmes and scope of scientific research. The analysis of statistical data for the last five years shows considerable reduction of printed editions from $2,851,139$ copies in 2014 to $1,967,543$ copies in 2018 (a fall of $30.9 \%$ ) with the a simultaneous
10 -times increase in the quantity of digital resources for the last three years from 65886 in 2016 up to 66191654 in 2018. Thus, the share of digital editions grows as well as the number of online media that do not have an analogue in a paper format.

Electronic editions provide a possibility of access to a necessary source for many users at the same time and electronic libraries are aimed at expanding the range of services, optimising the library stock organisation and providing new services. They implement the main principle - 'information here and now', and the trend of active electronic editions acquisition and preservation of printed ones will be supported further.

Readers are very important for the library activity. Statistics shows that every year the number of remote users increases. The number of the library readers and users of its services is given in Fig. 4.

The efficiency of the library work is defined by its attendance rate by different measures (Fig. 5). It is possible to note that the number of physical visits to the library has decreased for the recent four years from 542,628 in 2015 down to 223,175 in 2018 (down by 2.4 times). At the same time, the number of users addressing the library website has increased from 138,413 in 2016 up to 380,981 in 2018 (up by 2.75 times).

With the increase in the number of remote users, the number of issued documents (see

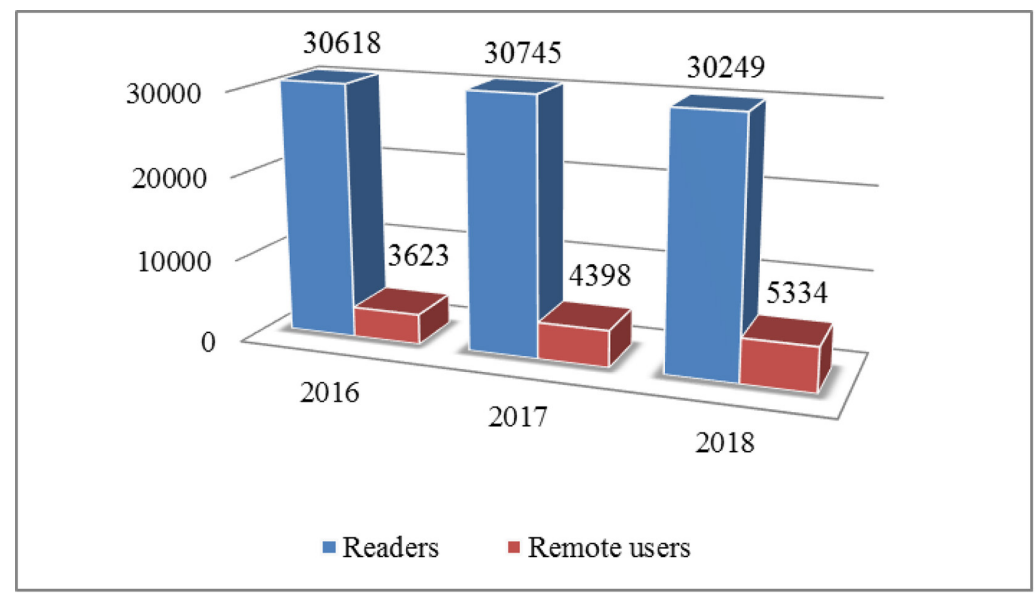

Fig. 4. Numbers of SibFU Scientific Library users 


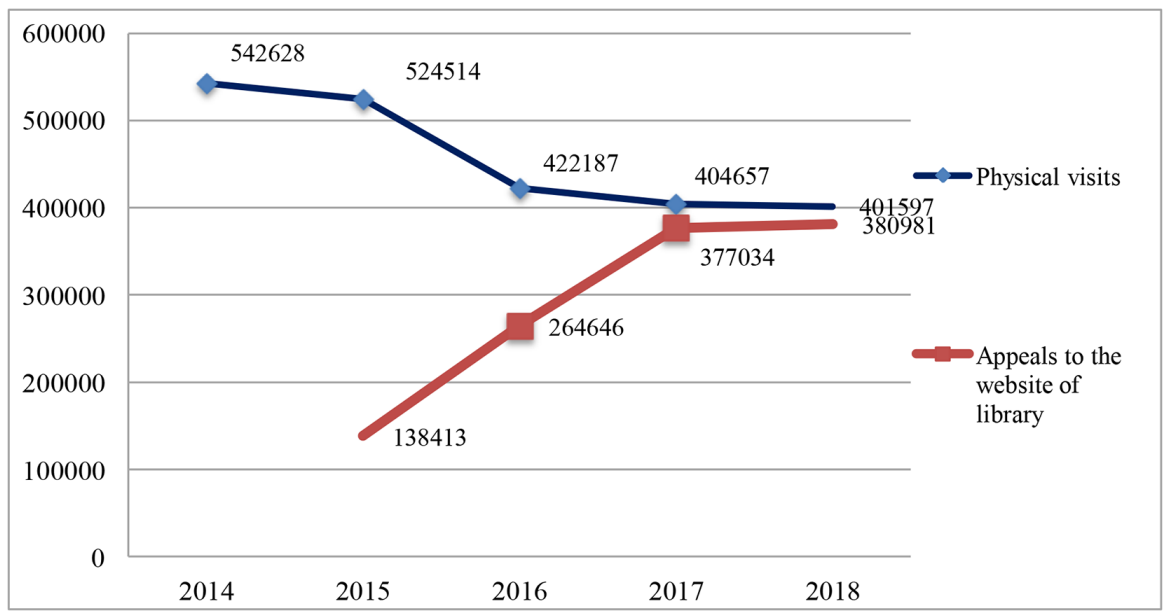

Fig. 5. Attendance rate of SibFU Scientific Library

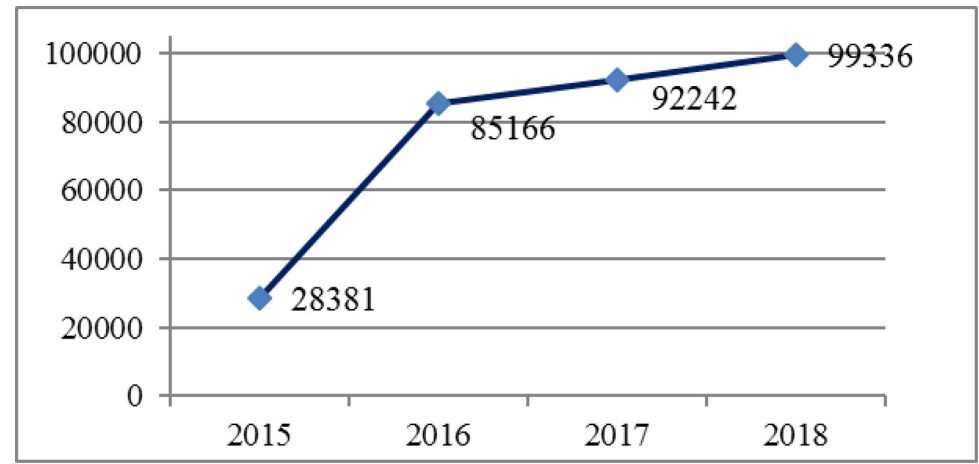

Fig. 6. The number of issued documents

Fig. 6) in digital form also grows. The data on the use of electronic resources presented in Fig. 6 are taken from the IRBIS automated library system. As for the statistics of the use of electronic resources from remote databases, it also shows positive dynamics of growth (2018409944 docs, 2017-353003 docs, 2016312009 docs). Today libraries offer their users different types of editions. Due to new technologies, information resources become available to all users. Students, scientists, faculty and administrative staff have an opportunity to take advantage of remote access to resources according to their information needs.

The general issue of documents in 2014 amounted to $1,165,766$ items from the library stock, and by 2018-379,938. Statistical data show that the number of printed editions issued has been reduced by 3 times, while use of electronic resources has increased by 3.5 times.

Within the smart library an element of services has been created for automated support of the university staff scientific and publishing work. Therefore it is possible to present results of SibFU staff scientific activity in the formation of information resources. For the past five years the number of scientific publications has grown considerably. At the same time it should be noted that not only a quantitative, but also a qualitative component of the university's publishing activity has increased (see Fig. 7).

As a result of publications in high-ranking scientific journals, the recognition of the Siberian scientists abroad has increased, as has their citation rate. From 2014 to 2018 this indicator almost doubled from 8868 to 20923 citations. 


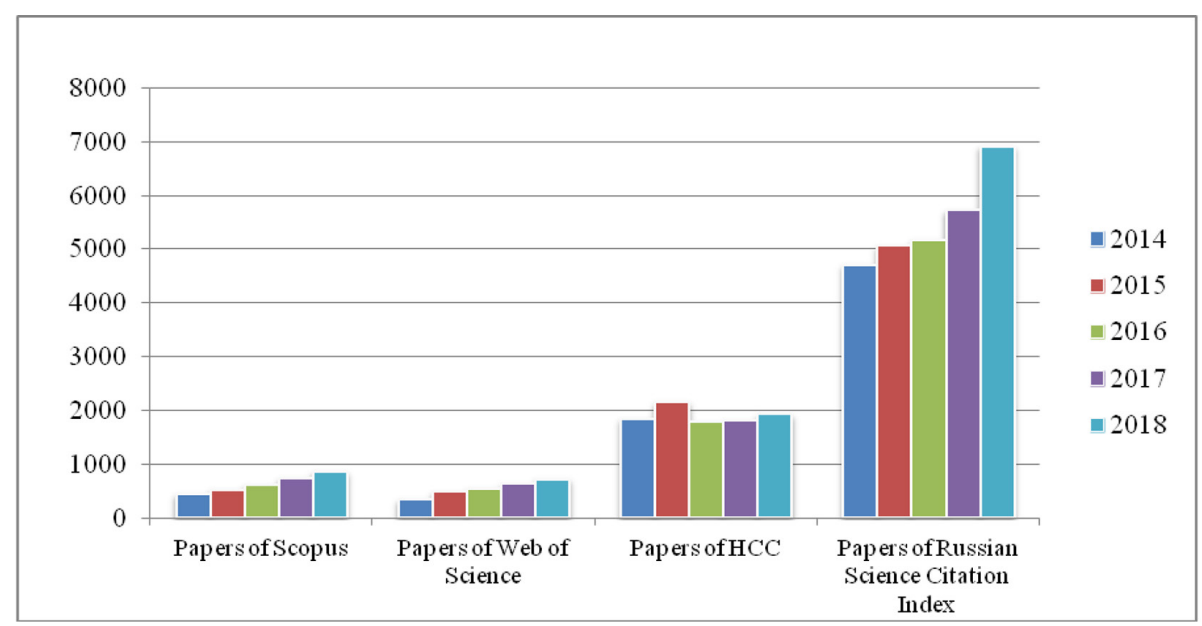

Fig. 7. SibFU employees' publishing activity

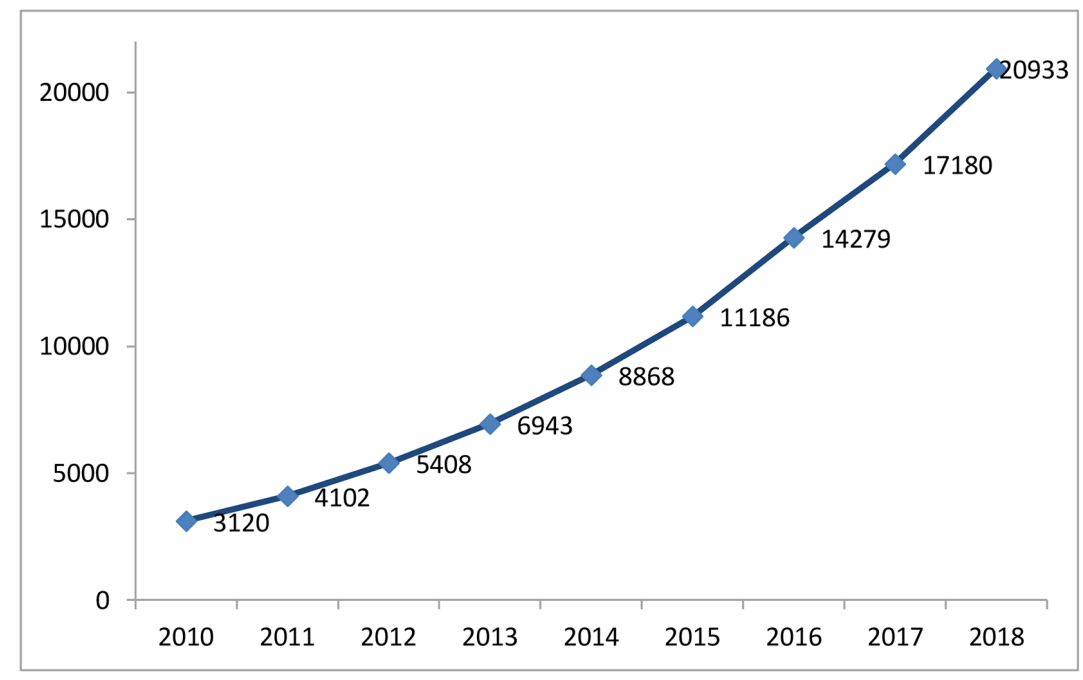

Fig. 8. SibFU employees' citation rate

The data on citing SibFU academic output are given in Fig. 8.

The received results allow us to conclude that the efficiency of the electronic resources use increases that allows satisfying the library users' inquiries to a full extent and support obtaining information quickly. Thus, the modern library transfers to a new stage of its development. On the one hand, it provides access to information resources that belong to other subjects of the information environment; on the other hand, it creates electronic resources available beyond it is the physical walls of the library. Besides, it renders virtual services in search for information and knowledge.

Besides, the readers have been asked what services of their personal account at the university library website they use. Only $50 \%$ of respondents use their personal accounts, $14 \%$ do not know about this service, $19 \%$ know about it but do not use it and $17 \%$ have ignored the question. In most cases the reader address their personal accounts to check what books they have borrowed and the deadlines on their use.

Next, the respondents have been asked to assess the quality of personal account ser- 
vices on a four-point system: satisfied; satisfied, but not completely; often not satisfied and not satisfied. According to their assessments it is possible to note that most of them are satisfied with the personal account services. For instance, $100 \%$ of the respondents are fully satisfied with the 'My library account'. They also have given good points to the following services: 'History of books issued' (89.4\%), 'Literature on academic disciplines' (76.6 \%), 'Verification of a work in Antiplagiarism system' (74.1\%). The survey has shown that the respondents who use their personal account services are satisfied with them in general.

To improve the library work the respondents had to propose necessary, in their opinion, new services. When they have replied the question about what extra library services they would like to use, most of them (78 \%) have replied that they are satisfied with everything, $22 \%$ have noted that they would like to get SMS or e-mail notification about the deadline of the borrowed books use and information about new arrivals and events held in the library.

To improve the library work the respondents have been asked the question what extra services should be included to their personal accounts. The respondents (87.2\%) would like their personal account space change automatically according to their personal preferences and the resources used before. The new service of automated submitting of information for research work has been supported by $59.8 \%$ of the respondents.

Thus, SibFU Scientific library users are satisfied with the library services in general. At first glance, the survey results show a high level of satisfaction and, therefore, it can be concluded that the information needs of the reader are met to an acceptable degree.

\section{Discussion}

The main research results consist of the following provisions:

1. The concept of the university smart library considered a system of providing information services to the reader in any form and on any medium, on the basis of classical and network forms of smart services, is approved.
2. The classification of services on various criteria, such as library activities (general services, scientific and educational services) and the ways of obtaining information (traditional; traditional implemented online services and smart services) has been developed.

3. The scheme of the university smart library has been presented.

4. The model of the university smart library is constructed representing the complex system including elements of various properties and difficulties and has the following advantages:

a) the user avoids the need to review large amount of information on their own in search for relevant information according to their interest;

b) the library offers information from sources that the user may not be aware of and therefore would never request. For example, the user can get articles from previously unknown journals, interdisciplinary information, books and monographs;

c) the library informs the user about updates related to their interests, new arrivals and published articles, eliminating the need for independent reviews;

d) anticipating the request, the library offers information that can go beyond the actual needs, creating a 'zone of immediate development' of interests and information needs of the user;

e) being active, the library can 'lead' the user, build a strategy for learning a discipline, a subject area, get scientific knowledge;

f) the library can select information and present it in the most convenient form for a particular user in the form of a text, audio, video, animation;

g) as a result of continuous analysis of the user's data, the information presented to the user will be individualised, and in some sense will be a reflection of the user's individual and personal characteristics.

\section{Findings and conclusion}

This paper emphasises the need for a library to be flexible and be able to adapt to changing needs and new technologies. The top priorities for all libraries are ensuring greater 
use of new technologies and interactive communication. The latter is possible with the help of smart library. A new library information environment has been developed and integrated into the university information space, providing qualitative information support for the teaching and learning process and scientific work.

The services presented in the current paper do not comprise a full list of possibilities offered by the smart library computerisation and automation. The system development works are being continued in the direction of the research papers' collection and aggregation, taking extensive references to resources and the improvement of search engines into account.

\section{References}

Aghakhani, N., Lagzian, F. and Hazarika, B. (2013). The role of personal digital library in supporting research collaboration. In The Electronic Library, 31, (5), 548-560.

Aithal, P.S. (2016). Smart Library Model for Future Generations. In International Journal of Engineering Research and Modern Education (IJERME), 1, (1), 693-703.

Bajic, E., Cea-Ramirez, A. and Dobre, D. (2008). Service modelling for smart objects in the supply chain using RFID and UPnP technologies, in Thorsten, B. (Ed.), RFID in Operations and Supply Chain Management: Research and Applications. Berlin: Erich Schmidt Verlag GmbH \& Co KG. p. 94

Baryshev, R.A. (2016). Experience of smart library development at Siberian Federal University: first results. In Higher Education Today, 1, 60-64.

Baryshev, R.A. and Babina, O.I. (2015). Services of the Personal Cabinet of the Scientific Library of Siberian Federal University for Teacher and Student. In Bibliosphere, 4: 41-48.

Baryshev, R.A., Babina, O.I., Zakharov, P.A., Kazantseva, V.P. and Pikov, N.O. (2015). Electronic library: genesis, trends. From electronic library to smart library. In Journal of Siberian Federal University. Series: Humanities, 8, (6), 1043-1051.

Baryshev, R.A., Babina, O.I. and Pikov, N.O. (2014). Methodical approaches to creation of smart library in university. In Electronic libraries, 17, (6).

Baryshev, R.A., Verkhovets S. V. and Babina O.I. (2018). The smart library project: development of information and library services for educational and scientific activity. In The Electronic Library, 36, (3), $535-549$.

Burgess, J.T.F. (2010). Smart-world technologies and the value of librarianship. In Computers in Libraries, 30, (10), 12-16.

Cao, G., Liang, M. and Li, X. (2018). How to make the library smart? The conceptualization of the smart library. In The Electronic Library, 36, (5), 811-825.

Dean, S., Nunan, K. and McDonald, V. (2010). Smart libraries build smart communities: future directions of the State Library of Queensland. In State Library of Queensland, 1-10.

Dong, Y. (2010). Smart library based on internet of things. In Journal of Library Science, 32, (7), 8-10.

Hubert, C.Y. and Chan, L. (2018). Smart library and smart campus. In Journal of Service Science and Management, 11, 543-564.

Hui, P. (2018). Research on the reading promotion mode of smart library. In International workshop on advances in social sciences, 720-725. 
Ivshina, G.V. (2017). Smart Library of Engineering University: View from Inside. In Electronic Libraries, 20, (6), 401-411.

Ivshina, G.V. (2017). Smart Space in Engineering University on the example of KNITU-KAI. In Scientists Notes ISGZ, 15, (1), 256-262.

Jeng, J. (2014). Exploring Digital Libraries: Foundations, Practice, Prospects by Karen Calhoun. In Libraries and the Academy, 14, (4), 653-654.

Johnson, I.M. (2013). Smart cities, smart libraries, and smart librarians. In Library Journal, 32, (1), $4-7$.

Kaklauskas, A., Zavadskas, E., Babenskas, E., Seniut, M., Vlasenko, A. and Plakys, V. (2007). Intelligent library and tutoring system for Brita in the PuBs project, LNCS4674 International Conference on Cooperative Design. In Visualization and Engineering, 157-166.

Kuleva, O.V. (2014). System of library and information service of remote users of the State Public Scientific Technical Library of the Siberian Branch of the Russian Academy of Science. In Works of State Public Scientific Technical Library of the Siberian Branch of the Russian Academy of Science, 7, 227-231.

Leorke, D., Wyatt, D. and McQuire, S. (2018). «More than just a library»: Public libraries in the 'smart city'. In City, Culture and Society, 15, 37-44.

Li, H. and Dong, F. (2016). Research on the implementation strategy of the smart library services. In Library, 260, (5), 80-84.

Little, G. (2013). The human connection. In The Journal of Academic Librarianship, 39, (5), 436-438.

Luterek, M. (2018). Smart city research and library and information science. Preliminary Remarks. In Zagadnienia Informacji Naukowej, 111, (1), 52-64.

Mohapatra, N., Basanta, K.D. (2017). Modern and smart library in the information age. In INFOLIB, $\mathrm{X}, 1-2$.

Nokhrin, Y.V. (2005). Digital library as a form of existing of library in information societies. Abstract of the thesis of the candidate of pedagogical sciences. Moscow, $18 \mathrm{p}$.

Noskov, M.V., Baryshev, R.A. and Manushkina, M.M. (2017). Electronic library in the context of the university's electronic information and education environment. Monograph. Moscow: 106.

Noskov, M.V., Shershnev, V.A., Baryshev, R.A. and Manushkina, M.M. (2016). Informatization of education in higher education institution: topical issues of digital libraries development. In Bulletin of the Tomsk state pedagogical university, 1 (166), 151-155.

Pan, Y.H. (2010). Important development for the digital libraries: data ocean and smart library. In Journal of Zhejiang University-Science C, 11, (11), 835-836.

Pandey, J., Kazmi, S.I.A., Hayat, M.S. and Ahmed, I. (2018). A study on implementation of smart library systems using IoT, International Conference on Infocom Technologies and Unmanned Systems. In Trends and Future Directions, 193-197.

Pinto, M. and Manso, R.A. (2012). Virtual references services: defining the criteria and indicators to evaluate them. In The Electronic Library, 30, (1), 51-69.

Schöpfel, J. (2018). Smart libraries. In Infrastructures, 3, (4), 1-11.

Schöpfel, J. (2017). Six futures of academic libraries. The End of Wisdom? In The Future of Libraries in a Digital Age, 123-128.

Shen, Yi. (2018). Emerging scenarios of data infrastructure and novel concepts of digital libraries in intelligent infrastructure for human-centered communities: A qualitative research. In Journal of Information Science, 45, (5), 691-704.

Shen, Yi. (2019). Emerging scenarios of data infrastructure and novel concepts of digital libraries in intelligent infrastructure for human-centered communities: A qualitative research. In Journal of information science, 45, (5), 691-704.

Simović, A. (2018). A Big Data smart library recommender system for an educational institution Library Hi Tech, 36, (3), 498-523.

Sreekumar, M.G. (2012). Strategies on e-resources management for smart information systems. In Annals of Library and Information Studies (ALIS), 59, (3), 155-169. 
Tryamkina, S.A. (2017). Digital library as a new form of library service in the Finno-Ugric world, In the collection: cultural worlds of Finno-ugriya: experience of the past in future models. In Materials of the All-Russian scientific and practical conference with the international participation, 286-291.

Tsibulsky, G.M., Noskov, M.V., Baryshev, R.A. and Somova, M.V. (2017). Active information system of higher education institution in the information and education environment. In Journal of Pedagogic, 3 , $28-32$.

Vasilieva, V. (2016). From e-services to smart library. University book, 10, 45-49.

Wang, H. (2017). Research on the current situations, problems and countermeasures of smart library constructions in China, Advances in Social Science. In Education and Humanities Research, 172, 36-39

Wang, S. (2012). On three main features of smart library. In Journal of Library Science, 22-28.

Wang, S. (2011). New pattern of future libraries: the smart library. In Library Development, 12, 1-5.

Wu, E. (2012). Smart library and the construction of its service model. In Information and Documentation Services, 33, (5), 102-105.

Yan, D. (2010). Smart library based on internet of things. In Journal of Library Science, 32, (7), 8-10.

Zadorozhnyuk, I.E., Kapochkina, I.P. and Stukalova, T.N. (2018). Traditions and innovations in information and library services. To the 75 anniversary of library of National Research Nuclear University MEPhI. In Scientific and technical libraries, 8, 36-47.

Zamyatin, A.M. (2011). Model of an electronic library system of higher education institution. In Journal of Young scientist, 4, (1), 89-91.

Zhang, H., Lin, P. and Li, X. (2018). The Construction of University's Smart Library. In Proceedings of the asia-pacific social science and modern education conference, 193, 12-15.

Zhang, N., Kang, Y. and Xiaobing, Z. (2019). Discussion on the wisdom learning space and library culture construction in the information age. Advances in Social Science. In Education and Humanities Research, 329, 1747-1749.

Zhao, J., Cai, W. and Zhu, X. (2019). Research on smart library big service application in big data environment. In Advances in Intelligent Systems and Computing, 877, 238-245.

Zimmerman, T. and Chang, H.C. (2018). Getting Smarter: Definition, Scope, and Implications of Smart Libraries. In Proceedings of the $18^{\text {th }}$ ACM/IEEE on Joint Conference on Digital Libraries, 403-404. 